\title{
THE 2016 REPUBLICAN PRIMARY GAMPAIGN ON TWITTER: ISSUES AND IDEOLOGICAL POSITIONING FOR THE PROFILES OF BEN CARSON, TED CRUZ, MARCO RUBIO, AND DONALD TRUMP
}

\author{
La campaña republicana en Twitter: tematización y \\ posicionamiento ideológico en los perflles de Ben \\ Carson, Ted Cruz, Marco Rubio y Donald Trump
}

\section{María Galán-García}

Nota: Este artículo se puede leer en español en:

https://recyt.fecyt.es/index.php/EPI/article/view/60009

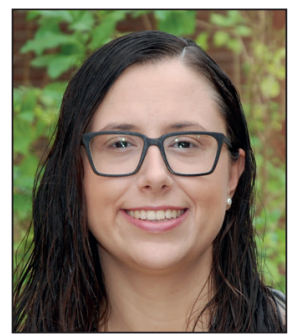

María Galán-García earned her PhD in Communication from the University of Valencia. Her dissertation examined the construction of Confederate propaganda speech during the American Civil War (1861-1865) and its effects on the Southern people. In addition to propaganda, her research interests include the analysis of political discourse and the use of new technologies of information and communication within this field.

http://orcid.org/0000-0001-8649-4336

Universitat de València Departamento de Teoría de los Lenguajes y Ciencias de la Comunicación Avda. Blasco Ibáñez, 32. 46010 València, Spain maria.galan@uv.es

\begin{abstract}
The 2016 Republican primaries, marked by Trump's controversial remarks and the dialectical confrontations between contenders, were mirrored on Twitter. This social network became the arena in which the candidates were able to express their views on different aspects and share with their potential voters both their concerns and the issues that would be the core of their electoral program if they were elected as the republican nominee. This paper analyzes the tweets published by the four best positioned candidates in the lowa polls (Ben Carson, Ted Cruz, Marco Rubio and Donald Trump), whose Caucus marks the beginning of the presidential primaries and whose results usually indicate how the presidential race is going to evolve, in the months prior to the beginning of the process and examines the main elements on which their respective campaigns were based and the ideological lines traced by each one on key issues for the Republican electorate, among other issues. The results introduce some of the electoral promises with which the winner of the primaries convinced the US voters to reach the Presidency.
\end{abstract}

\section{Keywords}

Twitter; Ideology; United States; Republican Party; Primaries; 2016 elections; Political communication; Electoral campaign.

\section{Resumen}

Las primarias republicanas de 2016, marcadas por las intervenciones de Trump y las confrontaciones dialécticas entre los contendientes, quedaron reflejadas en Twitter. La red social se convirtió en el espacio donde los candidatos pudieron expresar sus puntos de vista y compartir con sus potenciales votantes tanto sus preocupaciones como las cuestiones sobre las que pivotaría su programa electoral si resultaban elegidos. Este trabajo analiza los tweets publicados por los cuatro candidatos mejor posicionados en las encuestas de lowa (Ben Carson, Ted Cruz, Marco Rubio y Donald Trump), cuyo caucus marca el comienzo de las primarias y suele funcionar como medidor fiable de lo que va a ser la carrera presidencial, en los meses previos al inicio del proceso y examina los puntos sobre los que sustentaron sus campañas y las líneas que trazaron sobre temas clave para el electorado republicano, entre otras cuestiones. Los resultados introducen algunas de las principales promesas con las que el ganador de las primarias convenció a los votantes estadounidenses para alcanzar la Presidencia. 


\section{Palabras clave}

Twitter; Ideología; Estados Unidos; Partido Republicano; Primarias; Elecciones 2016; Comunicación política; Campaña electoral.

Galán-García, María (2017). "The 2016 Republican primary campaign on Twitter: Issues and ideological positioning for the profiles of Ben Carson, Ted Cruz, Marco Rubio, and Donald Trump”. El profesional de la información, v. 26, n. 5, pp. 850-858.

https://doi.org/10.3145/epi.2017.sep.07

\section{Background and introduction}

The consolidation of web 2.0. and the notable increase in the use of so-called social networking sites (SNSs) in recent years has led to a revolution in the way we understand political communication and to a momentous change in the relationship between the political class and their voters (Lilleker; Jackson, 2010; Towner; Dulio, 2012; Alonso-Muñoz; Marcos-García; Casero-Ripollés, 2016; Kruikemeier, 2014; Lilleker; Tenscher; Štětka, 2014). The use of SNSs as tools of political communication also represent a new stage in the professionalization process described by Gibson and Römmele (2001). From this point of view, after an initial communications phase, mainly based on the power of the local organization and face-to-face contact, a form of communication mediated through mass media is consolidated. This is later replaced by the development of increasingly specific campaigns designed by professionals specialized in political communication. At present, the emergence of modern technologies has favored a transformation, dominated by campaigns orchestrated by the politicians themselves and their inner circle of advisors in which the party has less and less weight (Enli; Skogerbø, 2013).

From this perspective, Barack Obama's presidential campaign in 2008 is considered to be the first notable example of the successful use of new technologies as tools to mobilize potential voters (Solop, 2009; Cogburn; Espinoza-Vasquez, 2011; Towner; Dulio, 2012; Lilleker; Tenscher; Štětka, 2014). This communications' strategy, based mainly on the effective use of the web and social networks such as Facebook, has become the model for subsequent electoral processes, and now includes a new actor: Twitter (Jungherr, 2016).

Created in 2006 by Jack Dorsey, this microblogging network based on spreading content using a maximum of 140 characters had a limited implementation when Obama reached the White House. However, its presence in the arena of American political communication increased substantially between 2008 and the mid-term elections of 2010 and, by the 2012 elections it had already become fully established (Golbeck; Grimes; Rogers, 2010; Hendriks; Kaid, 2011; Lassen; Brown, 2011; Hong; Nadler, 2012; Towner; Dulio, 2012; Conway; Kenski; Wang, 2013).

Among the advantages that have allowed Twitter to become one of the networks of preference among politicians, even rivaling with Facebook, one must highlight:

- the promise of democratic, horizontal, and decentralized communication;
- the possibility of direct contact with the voters, which allows the candidate to appear more personal; and

- the potential it offers for self-promotion and the viralization of messages, adjusting perfectly to the needs of the candidates in campaign (Jackson; Lilleker, 2009; Parmelee; Bichard, 2011; Rodríguez-Andrés; Ureña-Uceda, 2011; Conway; Kenski; Wang, 2013; Kruikemeier, 2014; Lilleker; Tenscher; Štětka, 2015; Moya-Sánchez; Herrera-Damas, 2015; Alonso-Muñoz; Marcos-García; Casero-Ripollés, 2016).

On the other hand, little or no interaction takes place between politicians and their voters, since the network is mainly used as a traditional communication platform and the unidirectional transmission of contents prevails (Grant; Moon; Grant, 2010; Barassi; Treré, 2012; Aragón et al., 2013; Zugasti-Azagra; Pérez-González, 2015).

\section{The Republican candidates}

Following the establishment of Twitter as the social network of reference during the 2012 Republican primaries, as proven by Conway, Kenski, and Wang (2013), the 2016 electoral process was presented as the ideal scenario to test Twitter's possibilities and try to make the most of them as a campaign tool. In this sense, our interest has been focused on the struggle for the Republican candidacy, due to two main factors:

- the atypical character of it, with more than ten candidates for the nomination at the beginning of the process against the three of the Democratic Party- and the weak position in the polls of those candidates closer to the establishment, who, a priori, should have been placed as the favorites;

- Donald Trump, winner of the Presidential election and enthusiastic Twitter user long before announcing his candidacy for the White House, supported with the motto Make America Great Again (\#MAGA on Twitter) (Neate, 2015).

In order to select candidates to further analyze we used the lowa caucus polls from late October 2015, which were the last polls published before the start of the analysis period (CNN/ORC, KBUR, Quinnipiac, PPP). In addition, lowa's selection as a referent is due to the fact that this is the state where the primary process begins and its results often work as a reliable meter to predict the outcome of the electoral race. Thus, despite having only thirty delegates at stake, a poor result in lowa usually turns into the anticipated end of a candidate's presidential bid.

Along with Trump, those polls placed Ben Carson at the top. Carson was a retired neurosurgeon with no political expe- 
rience who, like the real estate mogul, had built his campaign on the idea that it was necessary to give power back to the people (Terris, 2015). And, directly behind Trump and Carson were two candidates of Cuban heritage whose leap to the national political scene was linked to the emergence of the Tea Party (Abramowitz, 2011; Williamson; Skocpol; Coggin, 2011; Hook, 2015): Ted Cruz, a Senator for Texas since 2013, and Marco Rubio, a Senator for Florida since 2009 and whose support had begun to support for Cruz and Rubio had begun to surpass that of the theoretical candidate of the party: Jeb Bush (Bacon, 2015; Lema, 2015). This research focuses on these four candidates.

\section{Aims}

This article has three main aims which, in turn, include a series of research questions.

A1. To determine in what respect the four selected candidates supported their campaigns on Twitter

Q1. What weight was given to tweets devoted to electoral issues?

Q2. What were the principal issues for each candidate?

Q3. Were there any notable differences between candidates with previous political experience and the outsiders?

A2. To establish the ideological lines marked by each candidate on key issues for the Republican electorate: abortion, gun control, role of the Administration, etc.

Q4. For which candidates did these issues have a more significant presence?

Q5. Were there any differences in the stances taken by the candidates?

A3. To observe the impact that some events had on the ideas mentioned and how they affected the opinions expressed by the candidates

Q6. What use did candidates make of the events?

Q7. Which events did they mention and which ones did they omit?

Q8. Did these events signal a change or a reinforcement of a previously adopted position?

\section{Methodology}

In order to accomplish the above-mentioned objectives and answer the different questions raised, we used a double analysis, one quantitative and the other qualitative, of the tweets published by the four best positioned candidates at the beginning of the analysis period, between November 1 , 2015 and January 31, 2016, the day prior to the celebration of the lowa Caucus:

- Ben Carson (@RealBenCarson);

- Ted Cruz (@tedcruz);

- Marco Rubio (@marcorubio); and

- Donald J.Trump (@realDonaldTrump).

The selection of this short time period was made for two reasons:
1) to ensure a significant sample of tweets from the four candidates (with less time, there was a risk that Carson's sample would be too small; with more, that Cruz's and especially Trump's would be excessive) and,

2) to focus the analysis on the period closest to the beginning of the primary process because this is a time when aspects, such as the thematization or the ideological positioning of the candidates, begin to gain importance.

The tweets were collected by downloading them in html format and registering them individually in an Excel spreadsheet. Retweets were not considered, except in those cases where the candidate copies the message and publishes it himself (so that he appears as the author). In this way, we worked with a sample of 4,012 tweets, of which 549 belong to Carson; 1,063 to Cruz; 714 to Rubio; and 1,686 to Trump.

\section{Of the campaign issues of the four can- didates, foreign policy was the one that appeared most frequently (271 tweets)}

Regarding the quantitative analysis, the tweets were classified according to a proposal developed by Conway, Kenski, and Wang (2013). According to this approach, tweets are divided into four large blocks depending on their content:

- election issues (issues);

- campaign support (campaign-related media);

- past, present, or future campaign events (events); and - calls for action.

After this first classification -to which we have added a fifth block 'others' to encompass issues that do not fit the characteristics already defined- the analysis was focused almost exclusively on the tweets that referred to electoral topics.

Furthermore, within these electoral issues, a distinction was made depending on whether, or not, they referred to typical issues of mobilization of the Republican electorate (Petrocik, 1996; Damore, 2004; Abramowitz, 2011; Benoit et al., 2011; Conway; Kenski; Wang, 2013; Petrocik; Benoit; Hansen, 2003). In this sense, attention was paid mainly to the tweets focused on

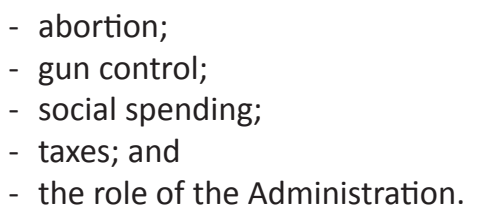

Finally, we pointed out the tweets that were motivated by or linked to some of the relevant events happening during the period of analysis, of which eight were selected:

- Paris attacks (November 13, 2015);

- Planned Parenthood shooting (November 27, 2015);

- Climate Change Summit (November 30- December 11, 2015);

- San Bernardino shooting (December 2, 2015);

- Capture (and release) of a group of American sailors by Iran (January 12-13, 2016); 
- Refugee crisis (the whole period);

- State of the Union speech and debate (January 12, 2016);

- Data about the economy and employment rate (the entire period).

As to the qualitative analysis, attention was devoted to identifying whether the candidates adopted a specific position on certain key issues (immigration, foreign policy, economy/ employment, education, and healthcare) and if they expressed their opinion on the aforementioned issues of mobilization of the electorate. In the affirmative cases, we clarified the positioning and added any specific proposals from candidates, either in the tweet itself or through some type of hyperlink. Finally, we observed whether their position was modified or intensified as a result of the events that marked the period of analysis.

\section{Results}

After analyzing the content of the tweets published by each of the four candidates on the selected dates, we observed that campaign themes, which in the study by Conway, Kenski and Wang (2013) represented 50.5\% of the analyzed tweets, were not the main issues for any of the four candidates chosen. From this perspective, Ted Cruz was who devoted the largest percentage of the published tweets to talking about campaign themes (35.94\%, 382 tweets), closely followed by Ben Carson (34.79\%, 191 tweets), and Marco Rubio (32.07\%, 229 tweets), while Donald Trump was the one who less often used Twitter for this purpose (26.93\%, 454 tweets).

Trump was the one who touched on fewer campaign issues, instead focusing more than a half of his posts on two matters: media (189 tweets) and opponents (172 tweets)

Thus, while Carson (48.82\%, 268 tweets), Cruz (44.40\%, 472 tweets), and Rubio (48.46\%, 346 tweets) devoted most of their tweets to talk about the campaign itself -either to promote their actions and inform about them or to request economic support from their followers-, in the case of Trump, almost half of the messages disseminated during the period of analysis (822) alluded to issues that had nothing to do with the electoral process in which he was immersed, and among those tweets, mentions to tweets of support received from anonymous citizens predominated.

Within the mentioned campaign issues, a total of 29 different subjects were counted, although only seven (defense/ army; economy/employment, foreign policy, gun control/ second amendment, healthcare/obamacare, refugees, religion) were referred to by the four candidates. Of these, foreign policy, with 271 tweets, was the one that appeared most frequently.

Looking at each candidate individually reveals more about the candidate's uses of Twitter. Ben Carson talked about nineteen different issues, although Foreign Policy and National Security/Terrorism were the questions to which he paid the greatest attention, with 45 and 37 tweets respectively.
None of the other themes appeared on more than twenty occasions, with four of them mentioned only once.

Ted Cruz, for his part, mentioned up to 25 different issues, even though most of his efforts were focused on Foreign Policy (101 tweets) and Immigration (61 tweets). On a second level, matters such as National Security/Terrorism (34), Economy/Employment (31), Gun Control/2nd Amendment (30), Opponents (27), and Government/Administration Roles (24) were mentioned. All other topics appeared ten times or less.

As for Marco Rubio, of the twenty issues he spoke about at some point, Foreign Policy was the one that was present most frequently, with 83 tweets, while of the remaining nineteen, only four were mentioned on more than ten occasions: Opponents (29), National Security/Terrorism (21), Gun Control/2nd Amendment (18), and Healthcare/Obamacare (13).

Cruz, with 74 tweets, was the candidate who most frequently resorted to the typical issues that mobilize Republican voters; Trump, with just one mention to gun control, was the one who devoted the least amount of attention to these issues

Finally, as far as Donald J. Trump is concerned, he was the one who touched on fewer campaign issues (13), focusing more than half of his interventions in this regard on two matters: Media, with 189 tweets, and Opponents, with 172 tweets. The third issue of importance was Foreign Policy (43), while the other aspects appeared much more marginally (only Immigration exceeded the figure of ten tweets).

Regarding the issues of mobilization of the Republican electorate, the intervention of the candidates was unequal. In this sense, Cruz was the one that most frequently referred to the five issues specified in this section, and he paid special attention to the role of the Administration and gun control. On the opposite side Trump, who, except for a single allusion to gun control, did not write about any of these issues. Among the candidates who did address these matters, gun control was, once again, the most mentioned aspect (58 tweets), followed by taxes (37), and the role of the Administration (33). On the contrary, social spending was the matter that provoked less interest, being mentioned only by Carson (Table 1).

Table 1. Subjects of Republican mobilization in candidates' tweets

\begin{tabular}{|l|c|c|c|c|}
\cline { 2 - 5 } \multicolumn{1}{l|}{} & Carson & Cruz & Rubio & Trump \\
\hline Abortion & 10 & 2 & 6 & 0 \\
\hline Gun control & 9 & 30 & 18 & 1 \\
\hline Social spending & 2 & 0 & 0 & 0 \\
\hline Taxes & 16 & 18 & 3 & 0 \\
\hline Role of the Administration & 6 & 24 & 3 & 0 \\
\hline
\end{tabular}




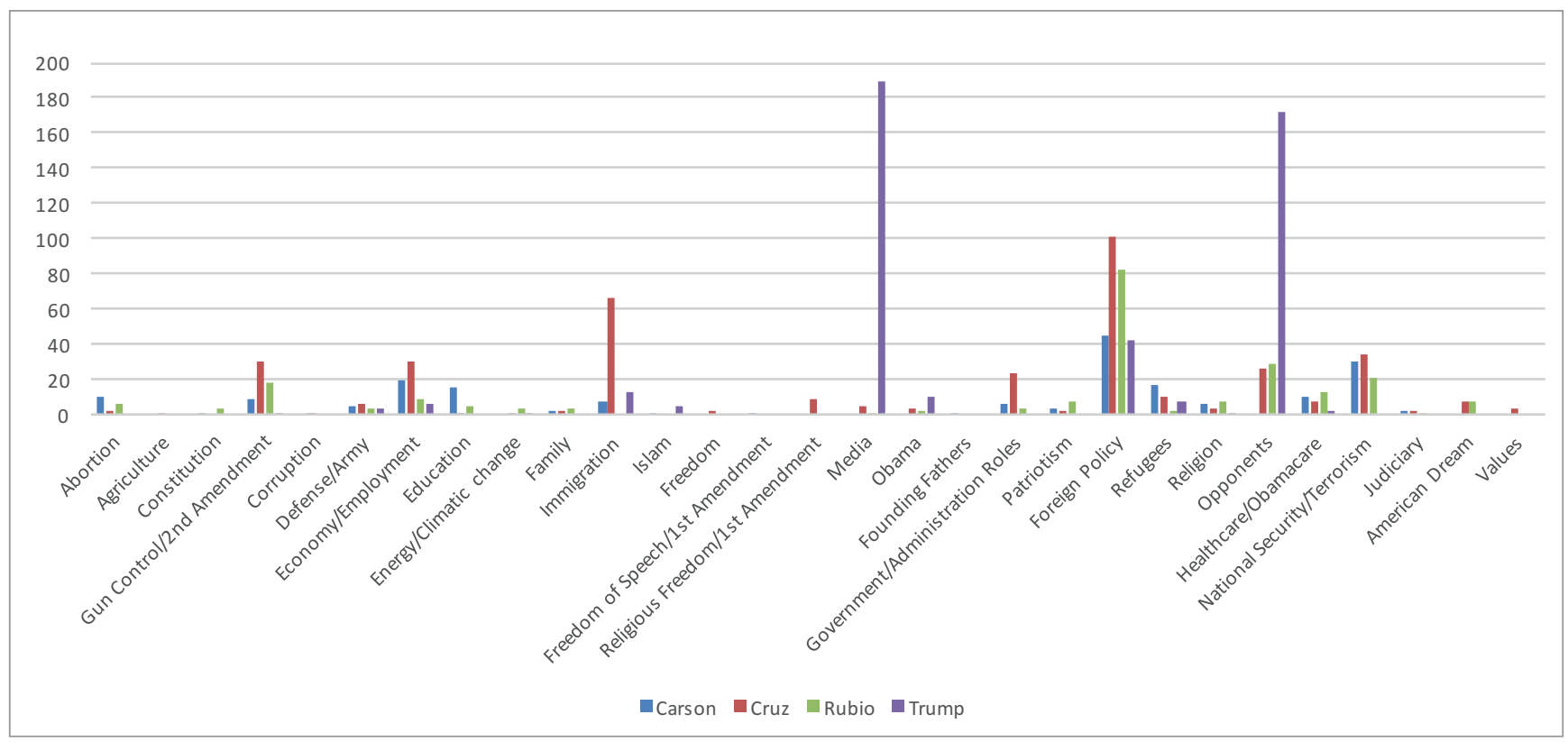

Figure 1.Tweets of the 4 candidates classified by topic

As for the presence of current events in the analyzed tweets, the attacks linked to Islamic terrorism were the most frequently named. In this sense, the San Bernardino shooting appeared in 46 tweets and the Paris attacks in 41 , both events were mentioned by all four candidates, although unevenly. On the other hand, there were no allusions to the (positive) data on the economy and employment; only Cruz devoted one tweet to the Planned Parenthood shooting in Colorado and only he and Trump made allusions to the Climate Summit celebrated in Paris.

By candidates, the events that Carson talked about most were the refugees crisis and the State of the Union speech and debate, while in the case of Cruz and Rubio this honor belonged to the Paris attacks and the San Bernardino shooting. These two events, along with the refugee crisis, were also the issues that had the most significant presence in Trump's messages, who was less prone to tweet in relation to the current events (Table 2).

Regarding the candidates' positioning on key electoral issues and the formulation (or not) of specific proposals, they varied depending on the subject and the candidate concerned.

Table 2. Events covered in candidates' tweets

\begin{tabular}{|l|r|r|r|c|}
\cline { 2 - 5 } \multicolumn{1}{c|}{} & Carson & Cruz & Rubio & Trump \\
\hline Paris attacks & 4 & 19 & 10 & 8 \\
\hline Refugee crisis & 17 & 10 & 2 & 8 \\
\hline Climate summit & 0 & 1 & 0 & 1 \\
\hline Economy / Employment data & 0 & 0 & 0 & 0 \\
\hline State of the Union & 16 & 6 & 3 & 2 \\
\hline Iran naval incident & 3 & 6 & 5 & 5 \\
\hline Planned Parenthood shooting & 0 & 1 & 0 & 0 \\
\hline San Bernardino shooting & 4 & 16 & 19 & 7 \\
\hline
\end{tabular}

In this sense, if attention was given to the issue of immigration, Carson expressed himself against the current system and proposed to reform it by strengthening borders and monitoring the immigrants who enter the country:

"As President, I will repair our immigration system by securing the border and implementing sensible admission and removal procedures" (@RealbBenCarson, 31/01/2016).

Cruz, for his part, was against the Obama amnesty program (which he blamed for the increase of insecurity in the country), advocated for more severe penalties for criminals who were also "illegal immigrants", proposed to secure borders by increasing border patrols, and suggested the establishment of limits on immigration:

"If I'm elected President, we will secure the border, we will solve this problem and there will NOT be amnesty" (@tedcruz, 05/11/2015).

Finally, Trump also opposed the amnesty and, as a way of ending "illegal immigration", proposed the construction of a wall, the reinforcement of borders, and the implementation of massive deportations:

“@AnnCoulter has been amazing. We will win and establish strong borders, we will build a WALL and Mexico will pay. We will be great again!" (@realDonaldTrump, 23/01/2016).

Rubio did not tweet about this matter, although both Trump and Cruz accused him of being an amnesty advocate.

As for foreign policy, the four of them coincided in talking about 'loss of international leadership' -of which they directly accused Obama- and in their opposition to the nuclear deal with Iran:

"Of the Obama-Clinton administration's many foreign policy mistakes, its nuclear agreement with Iran poses the greatest threat to America" (@RealBenCarson, 30/01/2016); 
"The Iran nuclear deal is the worst betrayal of American terror victims" (@tedcruz, 04/11/2015).

Regarding ISIS, however, they held different positions. Thus, Trump advocated bombing the oil fields; Cruz proposed the deployment of troops; Rubio talked about stopping them now and keeping them out of the United States (not specifying how) and Carson, who visited refugee camps in Jordan in November, merely suggested that the problem must be addressed at its source.

As for alliances and the identification of enemies, Cruz, Rubio, and Carson were in favor of Israel (Trump did not pronounce himself explicitly); Rubio and Carson talked about facing Russia and Putin; North Korea, Cuba, and Venezuela worried Rubio; and Libya was worrisome to Cruz. Trump did not insist specifically on any country, although he did point to Iran frequently.

\section{All four candidates talked about 'loss of international leadership', but they diffe- red on their identification of the main enemy of the United States. Regarding allies, the most favorable was Israel}

Among the issues related to the economy and employment, apart from tax proposals, only Cruz proposed a program of reforms aimed at increasing growth and to supporting the working class against large corporations. Trump, who did not make any concrete suggestions, merely said that if he reached the Presidency, he would put an end to offshoring to third countries.

As far as education was concerned, both Rubio and Carson wrote about the need to reform the system and "get the Federal bureaucracy" out of school:

"To be successful, we must take the federal bureaucracy out of education; concentrate on empowering the American people. We must \#ReviveEdu" (@RealBenCarson, 08/01/2016).

Cruz's proposal, in the only published tweet on this subject, was to abolish the Department of Education and end the Common Core. Trump did not dedicate any tweets to the subject.

Finally, regarding healthcare, the four of them agreed that they would revoke Obamacare, although none of them presented a concrete proposal, neither in the tweets, nor in the additional content (videos, links, etc.) linked to them:

"In my administration, we will repeal Obamacare and put control of health care back in to the hands of We the People" (@RealBenCarson, 21/12/2015);

"If I am elected President, we'll go to Congress and repeal every word of Obamacare" (@tedcruz, 04/01/2016).

If we take into account the position adopted by the candidates regarding the issues of mobilization of the Republican electorate, when addressing the issue of abortion, Carson, Cruz and Rubio were self-defined as 'pro-life', while Trump did not pronounce a position on Twitter.
Regarding gun control, all of them argued that the right to possess and carry arms was protected by the Constitution and that its limitation - which they pointed out as one of the aims of Hillary Clinton and the Democrats- was a violation of the Second Amendment:

“Obama's gun control executive order undermines the 2nd amendment and will do nothing to keep people safe" (@marcorubio, 06/01/2016);

"I have a proven record of defending the Second Amendment. As President, I'll continue to do the same \#2A \#GOPDebate" (@tedcruz, 15/01/2016).

As for the role of the state, they all talked about the need for reform. In this sense, Cruz and Rubio, the candidates with previous political experience, defended limiting the power of Washington and returning the power to the people, whereas Trump centered his criticism on the establishment, of which both Cruz and Rubio were a part.

Regarding social spending, Carson -the only one who explicitly wrote about it- talked about unemployment benefits to take a stance against them. Trump, while not speaking specifically on this issue, did comment on the introduction of reforms in Veteran Affairs (VA), the agency in charge of veterans from the U.S. Army.

Finally, when talking about taxes, both Carson and Cruz defended the implementation of a fixed tax plan, while Rubio simply opposed the application of new taxes:

"The \#CarsonFlatTax will simplify our burdensome tax code and give power back to We the People (@RealBenCarson, 06/01/2016);

"What our country needs is economic growth, and there is no new tax that leads to economic growth" (@marcorubio, 12/11/2016).

Trump, once again, did not write about it.

Trump did not make concrete proposals for the economy, employment, education, and healthcare. In addition, he did not take a position on abortion

Lastly, regarding the role of the events in modifying or reinforcing the positions adopted by the candidates, it is worth noting that both the Paris attacks and the San Bernardino shooting, the latter perpetrated by two Americans of Pakistani origin (and Muslims) were used by the four to justify their opposition to receiving refugees, to criticize Obama for his 'inaction' in front of what they all called 'radical Islamic terrorism' and to reaffirm their defense of greater border control as a measure of protection against future attacks:

"When will President Obama issue the words RADICAL ISLAMIC TERRORISM? He can't say it, and unless he will, the problem will not be solved!" (@realDonaldTrump, 15/11/2015);

"Whether Fort Hood, San Bernardino, or a number of others in between, President Obama's approach 
has been to treat each one in isolation" (@tedcruz, $10 / 12 / 2015)$

\section{Conclusion}

Given the socio-political circumstances at the time the tweets were gathered, it is not surprising that of all the campaign issues addressed by the candidates, Foreign Policy was the most important in the feeds of Carson, Cruz, and Rubio, for whom National Security also occupied a relevant place. It is noteworthy, however, that in the midst of the refugee crisis and with Trump placing the building of a wall on the Mexican border as one of the foundations of his campaign, only Cruz devoted considerable attention to the issue of immigration.

Likewise, it must be pointed out that in the case of Trump the most atypical of the candidates in terms of Twitter usage, the issues that appeared most often in his timeline were media and opponents. In this sense, Trump frequently used the social network to attack those media and journalists who criticized him -there were various tweets that pointed to his confrontation with Megyn Kelly, as well as some aimed at the media he identified as the opposition (mainly, CNN and The New York Times) - and to praise those who stood in his favor. In the case of opponents, the tweets written by Trump were oriented according to who he considered his main rival at each moment.

\section{The candidates made interesting use of current events, giving special relevance to those that allowed them to reinforce their position}

Similarly, what is remarkable was the limited attention given by candidates to some of the typical issues of mobilization of the Republican voters, especially in the case of the two people who had previous political experience (Cruz and Rubio). In this sense, of their tweets dedicated to campaign issues, Cruz mentioned these matters in $19.37 \%$ (74 tweets of 382) and Rubio in 3.10\% (30 tweets of 229), placing them both behind Carson, who talked about these issues in $22.51 \%$ of his tweets focused on campaign issues (43 tweets of 191). He was also the only one who dealt with the five predefined aspects. Trump, in accordance with his position as a political outsider, limited his attention to these matters to an isolated tweet on gun control that served him as an attack against Hillary Clinton $(0.22 \%$ of 454 tweets).

However, if we pay attention to the position adopted by the three candidates who, to a greater or lesser extent, talked about the aspects that supposedly concerned the traditionally Republican electorate, it is observed that there were no great differences between them. That is, the three of them were against abortion and gun control, took a stance in favor of the reform of the Administration and the reduction of taxes, and agreed that they would revoke Obamacare if they reached the Presidency, a measure that Trump also shared.
As for the key issues that could influence the undecided vote, in the case of immigration, Carson, Cruz, and Trump agreed on the need to reinforce borders, although they diverged in how to deal with undocumented immigrants. In terms of international affairs, ISIS was the topic that received the most attention and was singled out, together with Iran, as the main enemy; while all but Trump pointed directly to Israel as the great foreign ally of the United States.

Finally, regarding the use of events, the four candidates used those that allowed them to reinforce their position. Thus, all of them resorted to the Paris attacks and the San Bernardino shooting to justify their opposition to the reception of refugees and the need to strengthen US borders as the only defense against 'radical Islamic terrorism'. Likewise, the arrest and subsequent release of a group of US sailors by Iranian forces served to consolidate three ideas:

- Iran is one of the main enemies of the country;

- Obama's foreign policy has weakened the United States and made the US lose the respect of the international community, and

- the nuclear agreement reached with the Islamic Republic must be repealed as soon as possible.

They also all resorted, to a greater or lesser extent, to Obama's State of the Union address to attack the President and criticize his administration, pointing out those aspects that they intended to improve when they reached the Presidency. Those issues that could not be used in favor of their speech, nonetheless, were ignored by the candidates or treated in a very superficial way.

\section{Bibliography}

Abramowitz, Alan I. (2011). "Partisan polarization and the rise of the Tea Party movement". In: APSA 2011 Annual meeting.

https://papers.ssrn.com/sol3/papers.cfm?abstract_id=1903153

Alonso-Muñoz, Laura; Marcos-García, Silvia; Casero-Ripollés, Andreu (2016). "Political leaders in (inter)action. Twitter as a strategic communication tool in electoral campaigns". Trípodos, n. 39, pp. 71-90.

http://www.tripodos.com/index.php/Facultat_Comunicacio_ Blanquerna/article/view/381/435

Aragón, Pablo; Klapper, Karolin-Eva; Kaltenbrunner, Andreas; Laniado, David; Volkovich, Yana (2013). “Communication dynamics in Twitter during political campaigns. The case of the 2011 Spanish national election". Policy \& internet, v. 5, n. 2, pp. 183-206.

https://goo.gl/PZgJ7U

https://doi.org/10.1002/1944-2866.POI327

Bacon, Perry (2015). "As GOP race shifts, Carson, Cruz, Rubio and Trump are dominant players". NBC news, November 22. http://www.nbcnews.com/meet-the-press/gop-race-shiftscarson-cruz-rubio-trump-are-dominant-players-n467231

Barassi, Veronica; Treré, Emiliano (2012). "Does web 3.0 come after web 2.0? Deconstructing theoretical assumptions through practice". New media \& society, v. 14, n. 8, pp. 1269-1285

http://dx.doi.org/10.1177/1461444812445878 
Benoit, William L.; Glantz, Mark J.; Phillips, Anji L.; Rill, Leslie A.; Davis, Corey B.; Henson, Jayne R.; Sudbrock, Leigh-Anne (2011). "Staying 'on message': Consistency in content of presidential primary campaign messages across media". American behavioral scientist, v. 55, n. 4, pp. 457-468. https://goo.gl/AauFtT

https://doi.org/10.1177/0002764211398072

Cogburn, Derrick L.; Espinoza-Vasquez, Fatima K. (2011). "From networked nominee to networked nation: Examining the impact of web 2.0 and social media on political participation and civic engagement in the 2008 Obama campaign". Journal of political marketing, v. 10, n. 1-2, pp. 189-213. https://ucdenver.instructure.com/courses/337926/ files $/ 3219879 /$ download?wrap $=1$ https://doi.org/10.1080/15377857.2011.540224

Conway, Bethany-Anne; Kenski, Kate; Wang, Di (2013). "Twitter use by Presidential primary candidates during the 2012 campaign". American behavioral scientist, v. 57, n. 11, pp. 1596-1610.

https://goo.gl/No617G

https://doi.org/10.1177/0002764213489014

Damore, David F. (2004). "The dynamics of issue ownership in presidential campaigns". Political research quarterly, v. 57, n. 3, pp. 391-397.

https://goo.gl/yVPy77

https://doi.org/10.1177/106591290405700304

Enli, Gunn-Sara; Skogerb $\emptyset$, Eli (2013). “Personalized campaigns in party-centred politics. Twitter and Facebook as arenas for political communication". Information, communication \& society, v. 16, n. 5, pp. 757-774.

https://goo.gl/dhQbUW

https://doi.org/10.1080/1369118X.2013.782330

Gibson, Rachel; Römmele, Andrea (2001). "Changing campaign communications: A party-centered theory of professionalized campaigning". The international journal of press/ politics, v. 6, n. 4, pp. 31-43.

https://doi.org/10.1177/108118001129172323

Golbeck, Jennifer; Grimes, Justin M.; Rogers, Anthony (2010). "Twitter use by the U.S. Congress". Journal of the American Society for Information Science and Technology, v. 61, n. 8, pp. 1612-1621.

https://goo.gl/LcgCcS

https://doi.org/10.1002/asi.21344

Grant, Will J.; Moon, Brenda; Grant, Janie-Busby (2010). "Digital dialogue? Australian politicians' use of the social network tool Twitter". Australian journal of political science, v. 45 , n. 4, pp. 579-604.

https://openresearch-repository.anu.edu.au/handle/10440/1264 https://doi.org/10.1080/10361146.2010.517176

Hendriks, John-Allen; Kaid, Lynda-Lee (2011). Techno politics in presidential campaigning: New voices, new technologies, and new voters. New York: Rutledge. ISBN: 9780 415879781

Hong, Sounman; Nadler, Daniel (2012). "Which candidates do the public discuss online in an election campaign?: The use of social media by 2012 presidential candidates and its impact on candidate salience". Government information quarterly, v. 29, n. 4, pp. 455-461.

https://doi.org/10.1016/j.giq.2012.06.004

Hook, Janet (2015). "First three GOP presidential candidates share Tea-Party roots". The Wall Street journal, April 12. https://www.wsj.com/articles/first-three-gop-presidentialcandidates-share-tea-party-roots-1428867635

Jackson, Nigel A.; Lilleker, Darren G. (2009). "Building an architecture of participation? Political parties and web 2.0. in Britain". Journal of information technology \& politics, v. 6 , n. 3-4, pp. 232-250.

https://doi.org/10.1080/19331680903028438

Jungherr, Andreas (2016). "Twitter use in election campaigns: A systematic literature review". Journal of information technology \& politics, v. 13, n. 1, pp. 72-91.

https://goo.gl/rBshVZ

https://doi.org/10.1080/19331681.2015.1132401

Kruikemeier, Sanne (2014). "How political candidates use Twitter and the impact on votes". Computers in human behavior, v. 34, pp. 131-139.

https://goo.gl/LJCVax

https://doi.org/10.1016/j.chb.2014.01.025

Lassen, David S.; Brown, Adam R. (2011). "Twitter: The electoral connection?". Social science computer review, v. 29, n. 4, pp. 419-436.

https://goo.gl/AWWXv8

https://doi.org/10.1177/0894439310382749

Lema, Katy (2015). “Marco Rubio y Ted Cruz, a la altura de Donald Trump y Ben Carson en Google". El país, October 29. https://goo.gl/mLkTAc

Lilleker, Darren G.; Jackson Nigel A. (2010). "Towards a more participatory style of election campaigning: The impact of web 2.0. on the UK 2010 general election". Policy \& internet, v. 2, n. 3, pp. 67-96.

http://ipp.oii.ox.ac.uk/sites/ipp/files/documents/IPP2010_ Lilleker_Jackson_Paper_0.pdf

https://doi.org/10.2202/1944-2866.1064

Lilleker, Darren G.; Tenscher, Jens; Štětka, Václav (2015). "Towards hypermedia campaigning? Perceptions of new media's importance for campaigning by party strategists in comparative perspective". Information, communication \& society, v. 18, n. 7, pp. 747-765.

https://goo.gl/2NkmQ9

https://doi.org/10.1080/1369118X.2014.993679

Moya-Sánchez, Miguel; Herrera-Damas, Susana (2015). "Cómo puede contribuir Twitter a una comunicación política más avanzada". Arbor. Ciencia, pensamiento y cultura, v. 191, n. 774.

https://doi.org/10.3989/arbor.2015.774n4012

Neate, Rupert (2015). “Donald Trump announces US presidential run with eccentric speech". The guardian, June 16. https://www.theguardian.com/us-news/2015/jun/16/ donald-trump-announces-run-president

Parmelee, John H.; Bichard, Shannon L. (2011). Politics and the Twitter revolution: How tweets influence the relation- 
ship between political leaders and the public. Lanham, MD: Lexington Books. ISBN: 9780739165003

Petrocik, John R. (1996). "Issue ownership in presidential elections, with a 1980 case study". American journal of political science, v. 40, n. 3, pp. 825-850.

http://darp.Ise.ac.uk/Frankweb/courses/Ec501/petrocik_ issue_ownership.pdf

https://doi.org/10.2307/2111797

Petrocik, John R.; Benoit, William L.; Hansen, Glenn J. (2003). "Issue ownership and presidential campaigning, 1952-2000". Political science quarterly, v. 118, n. 4, pp. 599-626.

https://goo.gl/nm2fR8

https://doi.org/10.1002/j.1538-165X.2003.tb00407.x

Rodríguez-Andrés, Roberto; Ureña-Uceda, Daniel (2011). "Diez razones para el uso de Twitter como herramienta en la comunicación política y electoral". Comunicación y pluralismo, n. 10, pp. 89-116.

http://dadun.unav.edu/handle/10171/35625

Solop, Frederick I. (2009). “RT @BarackObama We just made history. Twitter and the 2008 presidential election". En: Hendricks, John-Allen; Denton, Robert E. Communicator-in-chief: A look at how Barack Obama used new media technology to win the White House. Lanham, MD: Lexington
Books, pp. 37-49. ISBN: 9780739141052

Terris, Ben (2015). "Ben Carson announces candidacy and says, 'I'm not a politician'”. The Washington Post, May 4. https://www.washingtonpost.com/news/post-politics/ wp/2015/05/04/ben-carson-announces-candidacy-andsays-im-not-a-politician/?utm_term=.f68b1a1f6282

Towner, Terri L.; Dulio, David A. (2012). "New media and political marketing in the United States: 2012 and beyond". Journal of political marketing, v. 11, n. 1-2, pp. 95-119. https://goo.gl/CdLD6m https://doi.org/10.1080/15377857.2012.642748

Williamson, Vanessa; Skocpol, Theda; Coggin, John (2011). "The Tea Party and the remaking of Republican conservatism". Perspectives on politics, v. 9, n. 1, pp. 25-43.

https://scholar.harvard.edu/files/williamson/files/tea_ party_pop.pdf

https://doi.org/10.1017/S153759271000407X

Zugasti-Azagra, Ricardo; Pérez-González, Javier (2015). "La interacción política en Twitter: el caso de @ppopular y @ahorapodemos durante la campaña para las elecciones europeas de 2014". Ámbitos: Revista internacional de comunicación, n. 28, pp. 38-49.

http://institucional.us.es/ambitos/?p=1697

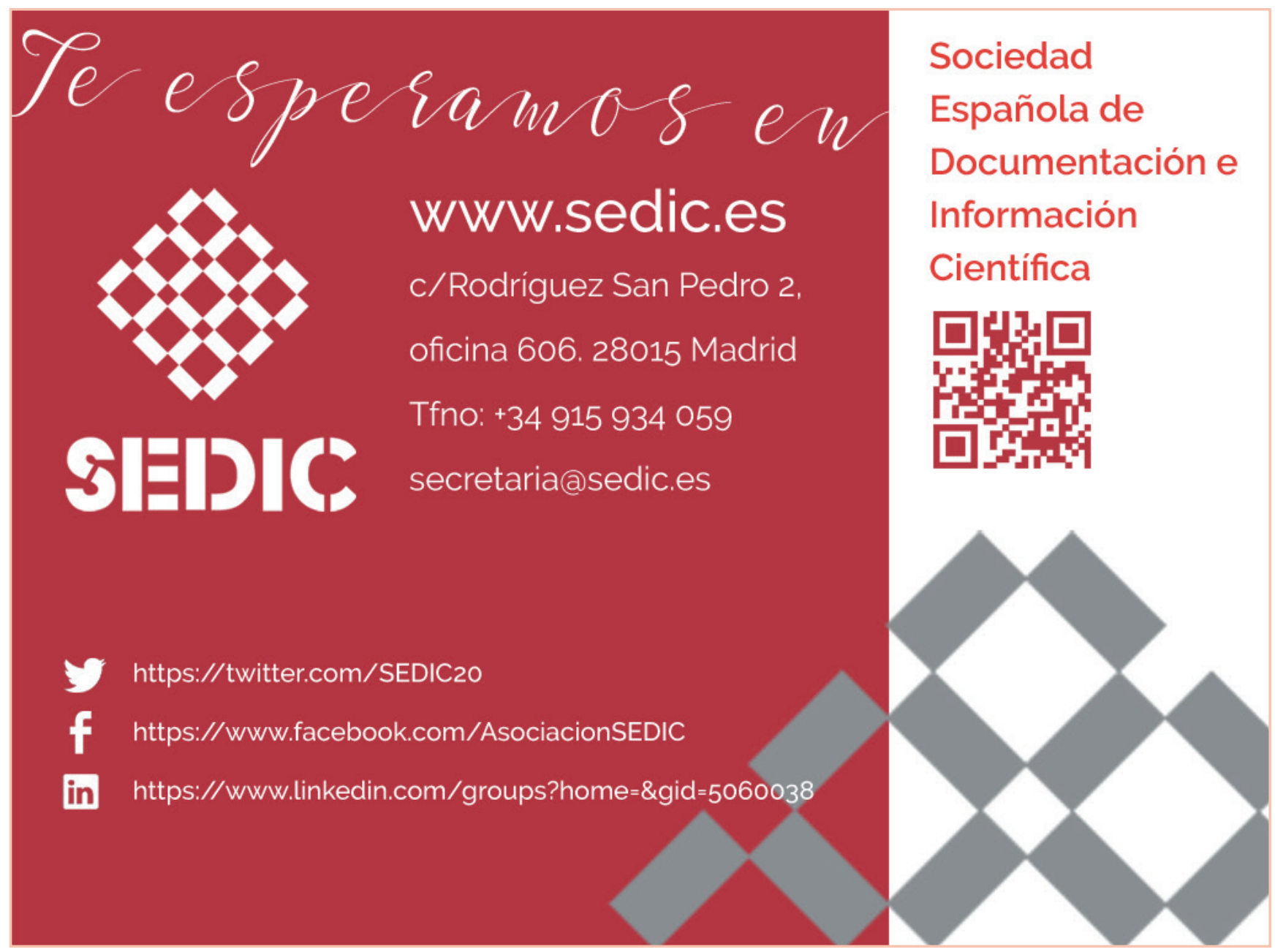

